\title{
ON THE HYERS-ULAM-RASSIAS STABILITY OF A PEXIDERIZED QUADRATIC INEQUALITY
}

\author{
KIL-WOUNG JUn AND YANG-Hi LEE
}

\begin{abstract}
In this paper we prove the stability of the Pexiderized quadratic inequality $\| f(x+y)+$ $g(x-y)-2 h(x)-2 k(y) \| \leqslant \varphi(x, y)$ in the spirit of D. H. Hyers, S. M. Ulam, Th. M. Rassias and P. Găvruta.
\end{abstract}

Mathematics subject classification (2000): Primary 39B72, 47H15.

Key words and phrases: Quadratic function, Pexiderized Quadratic equation.

\section{REFERENCES}

[1] P. W. CHOLEWA, Remarks on the stability of functional equations, Aeq. Math. 27 (1984), 76-86.

[2] S. CZERWIK, On the stability of the quadratic mapping in the normed space, Abh. Math. Sem. Hamburg 62 (1992), 59-64.

[3] Z. GAJDA, On the stability of additive mappings, Internat. J. Math. and Math. Sci. 14 (1991), 431-434.

[4] V. FAĬZIEV AND TH. M. RASSIAS, The space of $(\Psi, \gamma)$-pseudocharacters on semigroups.

[5] P. GĂVRUTA, A generalization of the Hyers-Ulam-Rassias stability of approximately additive mappings, J. Math. Anal. and Appl. 184 (1994), 431-436.

[6] D. H. HYERS, On the stability of the linear functional equation, Proc. Natl. Acad. Sci. U.S.A. 27 (1941), 222-224.

[7] D. H. Hyers AND TH. M. Rassias, Approximate homomorphisms, Aeq. Math. 44 (1992), 125-153.

[8] D. H. HyeRS, G. ISAC AND TH. M. RASSIAS, On the asymptoticity aspect of Hyers-Ulam stability of mappings, Proc. Amer. Math. Soc. 126 (1998), 425-430.

[9] D. H. Hyers, G. ISAC AND TH. M. RASSIAS, "Stability of Functional Equations in Several Variables”, Birkhäuser, 1998.

[10] G. IsAC AND TH. M. RASSIAS, On the Hyers-Ulam stability of $\psi$-additive mappings, J. Approx. Theory 72 (1993), 131-137.

[11] G. ISAC AND TH. M. RASSIAS, Functional inequalities for approximately additive mappings, , Stability of Mappings of Hyers-Ulam Type, Hadronic Press, Inc., Florida, (1994), 117-125.

[12] G. IsAC AND TH. M. RASSIAS, Stability of $\psi$-additive mappings: Applications to nonlinear analysis, Internat. J. Math. and Math. Sci. 19(2) (1996), 219-228.

[13] K. W. Jun D. S. Shin And B. D. KIM, On the Hyers-Ulam-Rassias Stability of the Pexider Equation, J. Math. Anal. Appl. 239 (1999), 20-29.

[14] S.-M. Jung, On the Hyers-Ulam-Rassias stability of approximately additive mappings, J. Math. Anal. Appl. 204 (1996), 221-226.

[15] S.-M. Jung, Pexiderized Quadratic Functional Equations.

[16] Y. H. LEE AND K. W. Jun, A Generalization of the Hyers-Ulam-Rassias Stability of Jensen's Equation, J. Math. Anal. Appl. 238 (1999), 305-315.

[17] Y. H. LEE AND K. W. Jun, A Generalization of the Hyers-Ulam-Rassias Stability of Pexider Equation, J. Math. Anal. Appl. 246 (2000), 627-638.

[18] Y. H. LeE AND K. W. Jun, A Note on the Hyers-Ulam-Rassias Stability of Pexider Equation, J. Korean Math. Soc. 37 (2000), 111-124.

[19] Y. H. LeE AND K. W. Jun, On the Stability of Approximately Additive Mappings, Proc. Amer. Math. Soc. 128 (2000), 1361-1369. 
[20] TH. M. Rassias, On a modified Hyers-Ulam sequence, J. Math. Anal. Appl. 158 (1991), 106-113.

[21] TH. M. RASSIAS, On the stability of the linear mapping in Banach spaces, Proc. Amer. Math. Soc. 72 (1978), 297-300.

[22] TH. M. RAssias, On the stability of functional equations in Banach spaces, J. Math. Anal. Appl., to appear.

[23] TH. M. RASSIAS, On the stability of functional equations and a problem of Ulam, Acta Math. Appl., to appear.

[24] TH. M. RASSIAS, On the stability of functional equations originated by a problem of Ulam, Studia Univ. "Babes-Bolyai", to appear.

[25] TH. M. RASSIAS, On the stability of the quadratic functional equation, Mathematica, to appear.

[26] TH. M. RASSIAS, On the stability of the quadratic functional equation and its applications, Studia Univ. "Babes-Bolyai", to appear.

[27] TH. M. Rassias, Report of the 27th Internat. Symposium on Functional Equations, Aeq. Math. 39 (1990), 292-293. Problem 16, $2^{o}$, Same report, p. 309.

[28] TH. M. RASSIAS AND P. ŠEMRL, On the behavior of mappings which does not satisfy Hyers-Ulam stability, Proc. Amer. Math. Soc. 114 (1992), 989-993.

[29] TH. M. RASSIAS AND J. TABOR, What is left of Hyers-Ulam stability?, Journal of Natural Geometry 1 (1992), 65-69.

[30] F. SKOF, Local properties and approximations of operators, Rend. Sem. Mat. Fis. Milano 53 (1983), $113-129$.

[31] S. M. Ulam, "Problems in Modern Mathematics", Chap. VI, Science eds., Wiley, Newyork, 1960. 